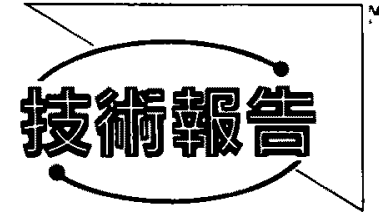

\section{8．新型転換炉 MOX燃料集合体の照射試験}

植松真 -*, 三次岳志*, 菊池圭一*, 小林哲朗**, 横谷 淳**

\author{
Irradiation Experiment of MOX Fuel Assembly for Advanced Thermal Reactor \\ By Shinichi UEMATSU, Takeshi MITSUGI, \\ Keiichi KIKUCHI, Tetsurou KOBAYASHI and Jun YOKOYA
}

\begin{abstract}
The Power Reactor and Nuclear Fuel Development Corporation (PNC) has developed the Advanced Thermal Reactor (ATR), which is a heavy-water moderated, boiling light-water cooled pressure-tube type thermal reactor. A 165 MWe prototype ATR called FUGEN has operated since 1979. More than 600 MOX assemblies have been irradiated in FUGEN without any failure.

As part of the first stage of the burn-up extention on the MOX fuel for thermal reactors, series of irradiation test were conducted on the 36-rod fuel assemblies. One test assembly was irradiated up to an assembly burn-up of $16.9 \mathrm{GWd} / \mathrm{t}$ in the SGHWR in UKAEA, three test assemblies were irradiated up to an assembly burn-up of 33.1 GWd/t in FUGEN. The results of post-irradiation exarninations (PIEs) were analyzed to elucidate the irradiation behavior of the MOX fuel.

The examination showed that there was no marked difference in irradiation behavior between MOX and $\mathrm{UO}_{2}$ fuel except for helium gas release and plutonium heterogeneity observed in a MOX fuel pellet. The acceptable performance of the ATR 36-rod fuel assembly has been verified.
\end{abstract}

KEYWORDS : mixed oxide fuels, fuel pellets, performance, ATR reactor, irradiation, radiation effects, post-irradiation examination

\section{I. 緒言}

熱中性子炬でのMOX然料の利用については, 海外の軽 水炉でこれまで累計 1,500 体以上の実績があり, 現在も実 用規模で継続的に行われてきているが，MOX燃料特有の 破損の事例は報告されていない。また，国内のBWRおよ び PWRでの少数体装荷においても，その健全性が確認さ れている。一方, BWR と同様のジルカロイ -2 製の然料被 㠅管を用いた重水減速沸騰軽水冷却型熱中性子炉である ATR 原型炬「ふげん」では, 昭和54年に本格運転を開始し て以来, 累計 600 体以上と一炝における世界最大の MOX 燃料の使用実績を有しており，すべて健全に使用されてい る。

本試験は熱中性子炉用MOX 燃料の燃焼度伸長のため, MOX 然料集合体の健全性の確認, 設計手法の妥当性の確 認执よび照射挙動データの取得を目的として, ATR 照射 用36本型 MOX燃料集合体の照射および照射後試験を実施 しだのである。

\section{II. 試験の内容}

\section{1. 照射用燃料集合体}

第 1 表および第 1 図に照射用燃料集合体(E03,E04, E05)

\footnotetext{
*動力炉·核㜣料開䊒事業団 (Power Reactor \& Nucl. Fuel Develop. Corp.)

**電源開発侏 (Elec. Power Develop. Co., Ltd.) （1997年4月10日 受理）
}

の主要諸元および構造を，英国(UKAEA)のSGHWRに おいて照射された ATR 照射用36本型 MOX 燃料の Type-Eと合わせて示す。照射用然料集合体は，スペーサ を支持するスベーサ支持管の周囲に 36 本の燃料要素を同心 円状に 3 層配列し，上部および下部タイプレート並びにス ペーサにより支持, 固定した構造となっている。また，中 間層の然料要素のうち 6 本は夕イロッドであり，上下の夕 イプレートを結び付ける役目をしている。上部タイプレー 卜は，然料要素とスペーサ支持管の上部端栓部にあるロッ ドスプリングを介して，ロックナットにより固定されてい る。然料要素は, 被覆管, 上部および下部端栓,ペレット並 びに上部执よび下部プレナムスプリングからなり，Heを 封入してある。ペレットは，マイクロ波加熱脱硝法による 混合転換粉を天然 $\mathrm{UO}_{2}$ 粉とボールミルにより機械混合し たすのを用いて作られたすのである。なお，Type-Eでは $\mathrm{PuO}_{2}$ 粉を天然 $\mathrm{UO}_{2}$ 粉とボールミルにより機械混合したも のを用いて作られたものである。

これらの照射用燃料集合体は，動力炬·核燃料開発事業 団(動燃)東海事業所において，「ふげん」の炉心燃料として 使用されている28本型MOX 燃料集合体と同様の製造工程 に従って製造し，この際に照射後試験結果の検討に必要な 各種の製造時データを採取した。

\section{2. 照射および照射後試験}

E03，E04およびE05については，「ふげん」にいて照射 を行い, E04 は約 1 年間, E05は約 2 年間の冷却·保管の 


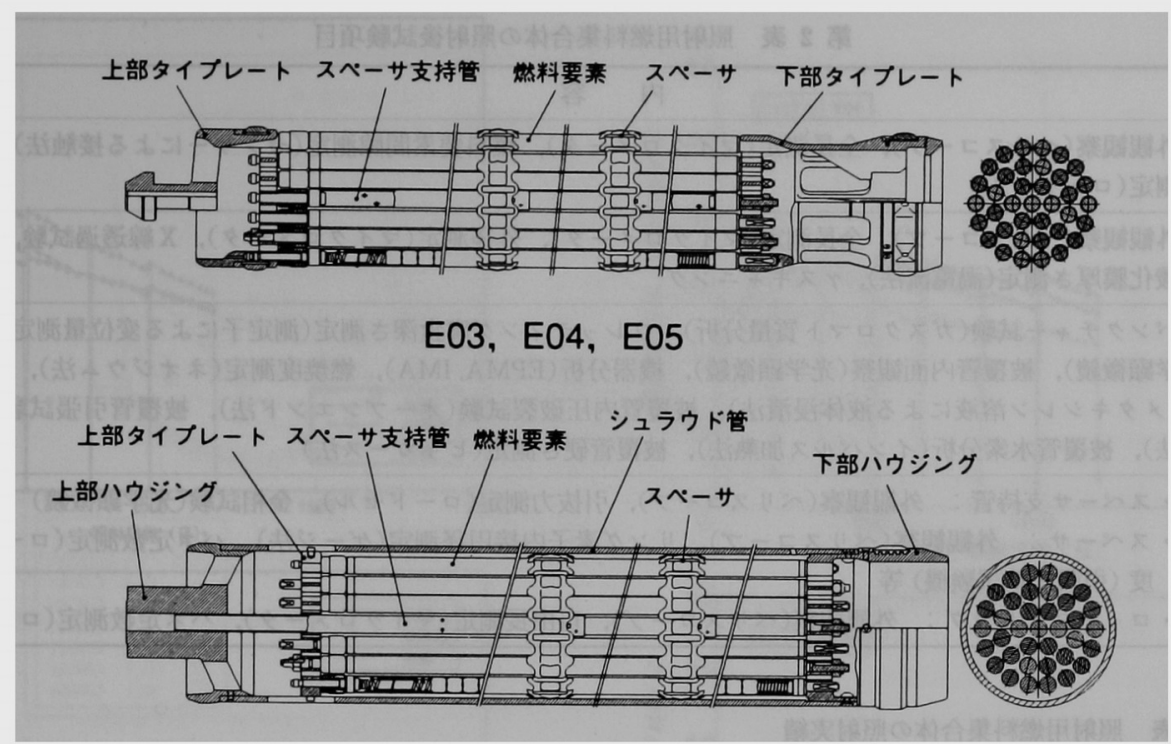

SGHWR TYPE - E

第 1 図 燃料集合体構造図

第 1 表 照射用燃料集合体の主要諸元

\begin{tabular}{|c|c|c|c|}
\hline \multicolumn{2}{|c|}{ 項 目 } & $\mathrm{E} 03, \mathrm{E} 04, \mathrm{E} 05$ & Type-E \\
\hline \multicolumn{4}{|l|}{ 燃料集合体 } \\
\hline 全 長 & $(\mathrm{mm})$ & 4,398 & 4,084 \\
\hline 然料要素 & (本) & 36 & 36 \\
\hline スペーサ支拱 & 寺管 （本） & 1(ジルカロイ2) & 1(ジルカロイ2) \\
\hline スペーサ & (個) & \multicolumn{2}{|c|}{ 12(インコネル718) 11(インコネル718) } \\
\hline \multicolumn{4}{|l|}{ 燃料要素 } \\
\hline 有効長 & $(\mathrm{mm})$ & 3,647 & 3,410 \\
\hline \multirow[t]{2}{*}{ プレナム長 } & \multirow[t]{2}{*}{$(\mathrm{mm})$} & 上部 355 & 上部 330 \\
\hline & & 下部 30 & 下部 30 \\
\hline 充填 He ガス & 圧 (MPa) & 0.3 & 0.1 \\
\hline \multicolumn{4}{|c|}{ 被復管 } \\
\hline 外径 & $(\mathrm{mm})$ & 14.50 & 14.50 \\
\hline 内 径 & $(\mathrm{mm})$ & 12.70 & 12.69 \\
\hline 表面粗さ & $(\mu \mathrm{mRa})$ & 0.8 & 0.8 \\
\hline 材質 & & ジルカロイ2(SR材) & ジルカロイ2(SR材) \\
\hline \multicolumn{4}{|l|}{ ペレット } \\
\hline \multirow[t]{2}{*}{ 外 径 } & \multirow[t]{2}{*}{$(\mathrm{mm})$} & \multirow[t]{2}{*}{12.40} & 12.40 \\
\hline & & & 12.57 \\
\hline 高さ & $(\mathrm{mm})$ & 13 & 13 \\
\hline ディッシュ & & $7 \mathrm{~mm} \phi, 0.2 \mathrm{mmh}$ & $7 \mathrm{~mm} \phi, 0.18 \mathrm{mmh}$ \\
\hline チャンファ & & $11 \mathrm{~mm} \phi, 0.3 \mathrm{mmh}$ & $11 \mathrm{~mm} \phi, 0.3 \mathrm{mmh}$ \\
\hline 密度 & (\%T.D.) & 95 & 95 \\
\hline 表面粗さ & $(\mu \mathrm{mRa})$ & 1.6 & 1.6 \\
\hline \multirow[t]{3}{*}{ Puf 富化度 } & \multirow[t]{3}{*}{ (wt\%) } & 内 層 2.45 & \multirow[t]{3}{*}{1.06} \\
\hline & & 中間層 2.45 & \\
\hline & & 外 層 0.98 & \\
\hline \multirow[t]{2}{*}{$\mathrm{PuO}_{2}$ 富化度 } & \multirow[t]{2}{*}{$(w t \%)$} & $\begin{array}{l}\text { 内 層 } 3.27 \\
\text { 中間層 } 3.27\end{array}$ & \multirow[t]{2}{*}{1.38} \\
\hline & & 外 層 1.31 & \\
\hline U婊縮度 & $(w t \%)$ & 0.71 & 0.71 \\
\hline
\end{tabular}

後, 日本原子力研究所東海研究所および動燃大洗工学セン ターにて照射後試験を実施した。なお, Type-Eについて は，UKAEAの SGHWRにおいて照射を行い，約 7 力月 間の冷却・保管の後, UKAEAのウィンズケール研究所に て照射後試験を実施した。第 2 表に照射後試験項目を示 す。また, 照射中には原子炉熱出力, 出力分布, 冷却材水質 等のデータを定期的に採取し，これをもとに線出力密度， 燃焼度, 高速中性子照射量等を計算して照射後試験結果の 检討に利用した。

\section{III. 照 射}

第 2 7 図に各燃料要素ごとの平均燃焼度履歴, 平均線 出力密度䪖歷, 平均高速中性子束㠅歴等の照射履歴を示す。 また，第 3 表に照射用然料集合体の主な照射実績を， Type-Eのあのとともに示す。照射用燃料集合体の燃焼度 は集合体平均で $33.0,25.1,33.1 \mathrm{GWd} / \mathrm{t}$, 燃料要素最大で $40.2,31.1,40.3 \mathrm{GWd} / \mathrm{t}$ であり, その線出力密度は燃料 要素最高で $43.8 ， 44.5,43.8 \mathrm{~kW} / \mathrm{m}$ を経験している。ま た，照射中の冷却材水質については，燃料の健全性の観点 から，導電率，八ロゲン，溶存酸素等に問題となるような異 常な変化はみられず，また，燃料破損を示すような放射能 レベルの上昇あみられなかった。

\section{IV. 照射後試験}

\section{1. 燃料集合体の照射挙動}

（1）磪全性

写真 1 に超音波洗浄後の然料集合体の外観の代表例を示 す。すべての燃料集合体は，異常な変形や損傷は認められ ず，正常な状態であることが確認された。 
第 2 表 照射用燃料集合体の照射後試験項目

\begin{tabular}{|c|c|}
\hline 項 目 & （）内は試験方法 \\
\hline $\begin{array}{l}\text { 燃料集合体 } \\
\text { 試 験 }\end{array}$ & 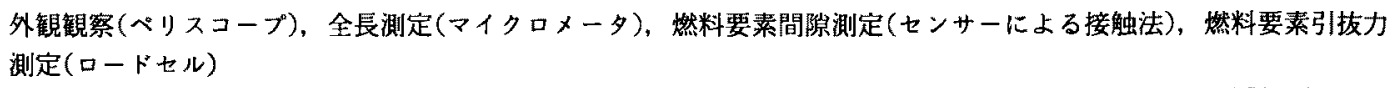 \\
\hline $\begin{array}{l}\text { 燃料 要 素 } \\
\text { 非破填試験 }\end{array}$ & 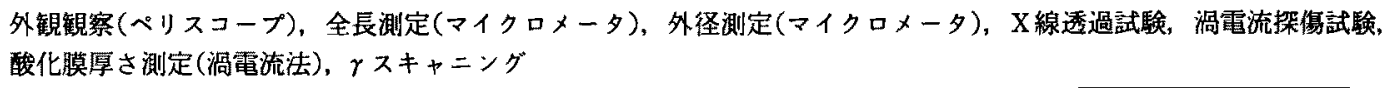 \\
\hline $\begin{array}{l}\text { 燃料要菜 } \\
\text { 破壊試験 }\end{array}$ & 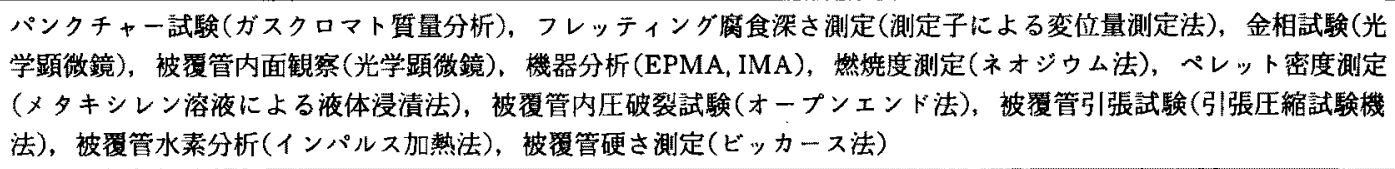 \\
\hline $\begin{array}{l}\text { 然料集合体 } \\
\text { 部材試験 }\end{array}$ & 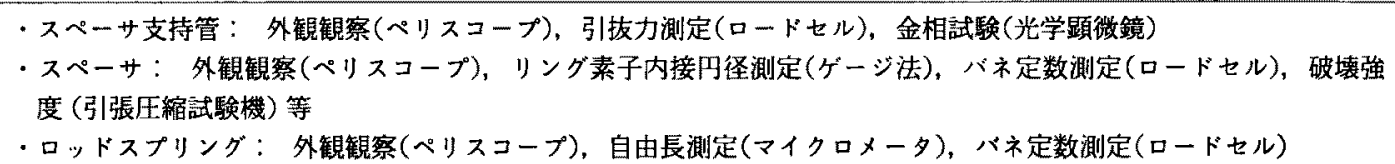 \\
\hline
\end{tabular}

第 3 表 照射用然料集合体の照射実績

\begin{tabular}{|c|c|c|c|c|}
\hline 項 目 & E03 & E04 & E05 & Type-E \\
\hline 照射日数 (EFPD) & 1,641 & 1,157 & 1,641 & 890 \\
\hline \multicolumn{5}{|l|}{ 燃焼度 (GWd/t) } \\
\hline 燃料集合体平均 & 33.0 & 25.1 & 33.1 & 16.9 \\
\hline \multicolumn{5}{|l|}{ 燃料要素平均 } \\
\hline 内 層 & 29.7 & 21.8 & 29.8 & 13.6 \\
\hline 中間層 & 35.4 & 27.2 & 35.5 & 15.3 \\
\hline 外 層 & 32.5 & 24.8 & 32.6 & 19.0 \\
\hline \multicolumn{5}{|l|}{ 燃料要素最高 } \\
\hline 内 層 & 34.7 & 25.8 & 34.7 & 16.7 \\
\hline 中間瘄 & 40.2 & 31.1 & 40.3 & 18.6 \\
\hline 外 層 & 37.2 & 28.3 & 37.3 & 22.9 \\
\hline \multicolumn{5}{|l|}{ 最大線出力密度 } \\
\hline \multicolumn{5}{|l|}{$(\mathrm{kW} / \mathrm{m})$} \\
\hline 内 層 & 29.5 & 30.0 & 29.5 & 23.7 \\
\hline 中間層 & 41.2 & 41.7 & 41.2 & 28.9 \\
\hline 外 層 & 43.8 & 44.5 & 43.8 & 42.6 \\
\hline \multicolumn{5}{|l|}{ 最大高速中性子照射量 } \\
\hline$\left(10^{25} \mathrm{~m}^{-2}\right)$ & 4.52 & 3.28 & 4.52 & 2.37 \\
\hline 冷却材温度 $\left({ }^{\circ} \mathrm{C}\right)$ & 284 & 284 & 284 & 282 \\
\hline 冷却材压力 (MPa) & 6.9 & 6.9 & 6.9 & 6.7 \\
\hline
\end{tabular}

\section{（2）寸法変化}

然料集合体の全長の伸びは最大で $0.41 \%$ (E05)であり， 設計上考虑している伸び率 $0.79 \%$ (E05)を下回っていた。 また，燃料要素間隙の測定結果から，燃料要素の自重によ る圧縮荷重が大きく，スペーサ間隔が大きい燃料集合体下 方での燃料要素曲がりが比較的大きくなっていたと考えら れるが，設計上考虑している曲がり量を下回っており，燃 料要素間隙閉塞に対して問題となるような量ではなかっ た。

\section{2. 燃料要素の照射挙動}

\section{(1) 健全性}

燃料要素の表面には，ノジュラー腐食, スペーサ部のフ ローマーク, 後述するように, ノシュラー噟食加集積した
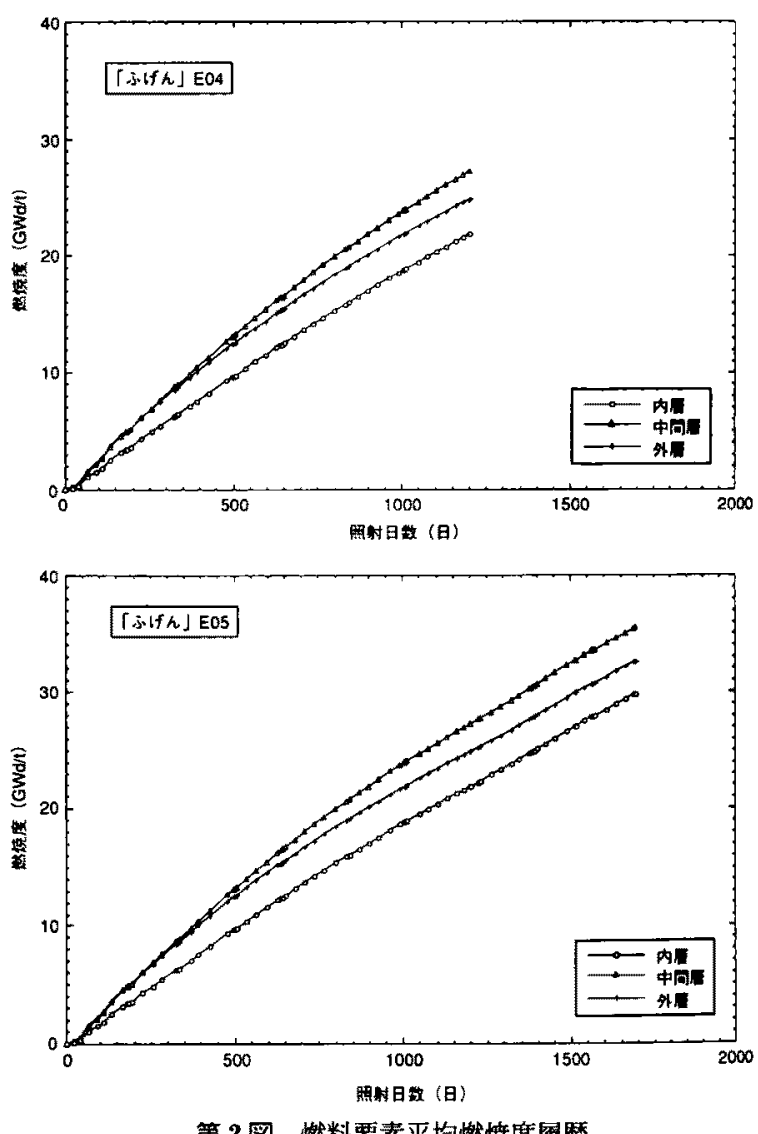

第 2 図 然料要菜平均然㜔度履歴

ペレット間隔での白色線状の模様が観察されたが, 渦電流 探賃試験, X線透過試験等で被覆管に欠陥や佰等は認めら れず,いずれの燃料要素も健全であることを確認した。

(2) 寸法変化

第 8 図に燃料要素全長の伸びの燃焼度依存性を他の照射 データ(1) (3) と併せて示す。本試験での燃料要素全長の伸 びは他の照射データの範囲内であり，燃料要素間の伸び差 あロッドスプリングの縮み余裕の範囲内であった。 

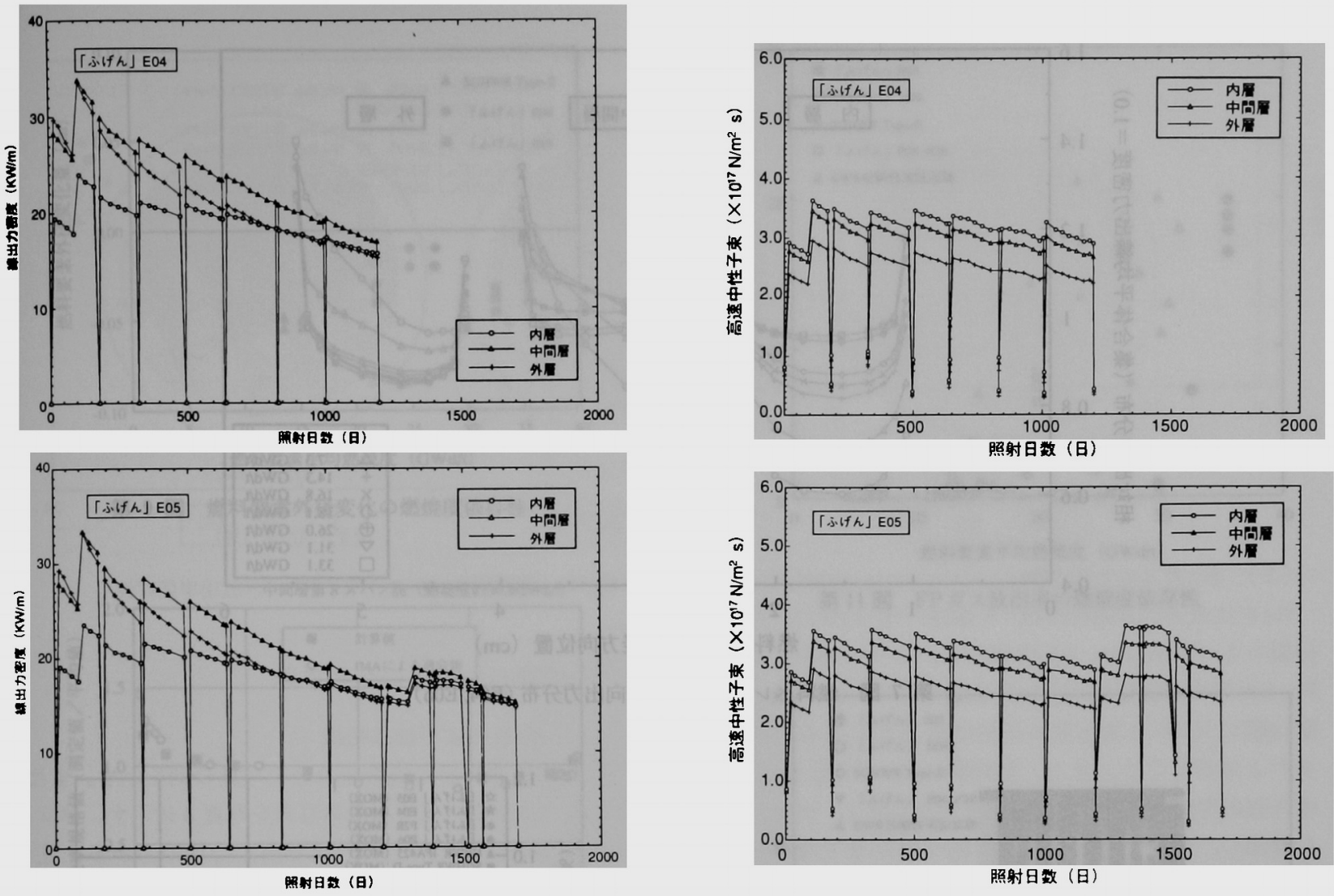

第 3 図 燃料要素平均線出力密度履歷

第 4 図 燃料要素平均高速中性子束履歴
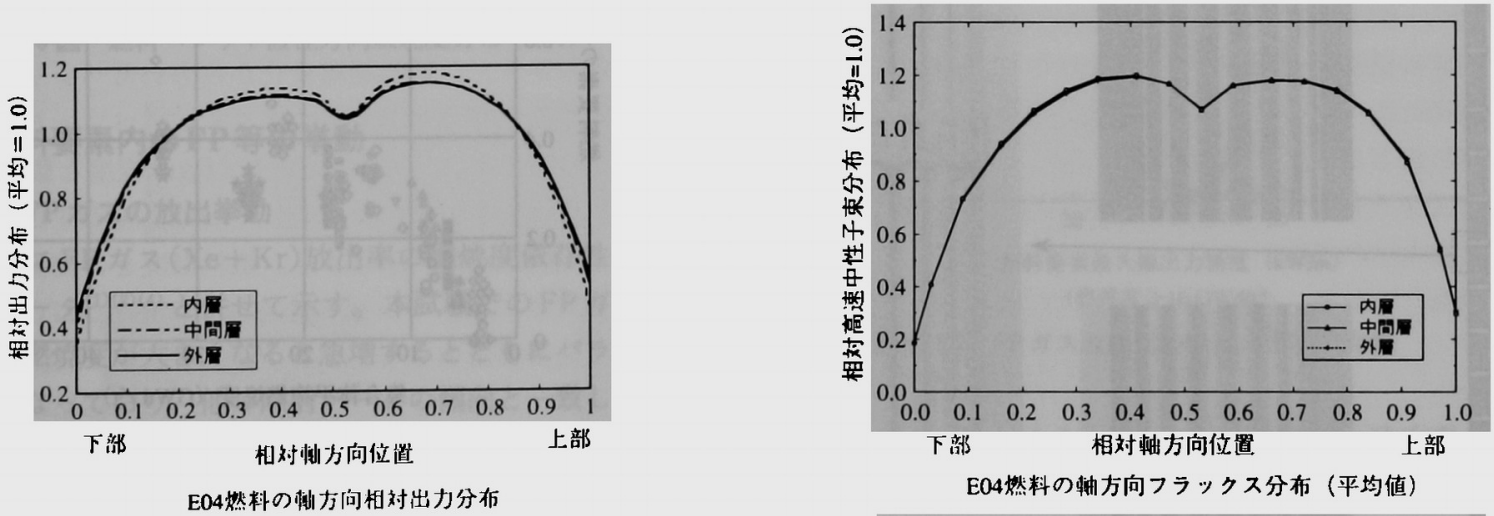

E04燃料の軸方向フラックス分布（平均值）

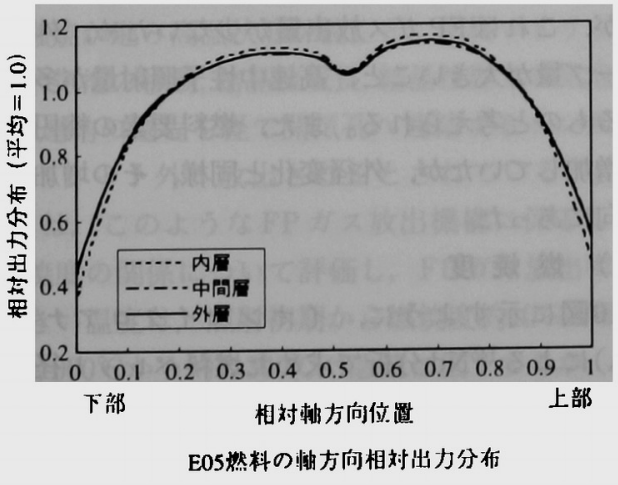

第 5 図㜣料要素軸方向相対出力分布 (寿命平均)

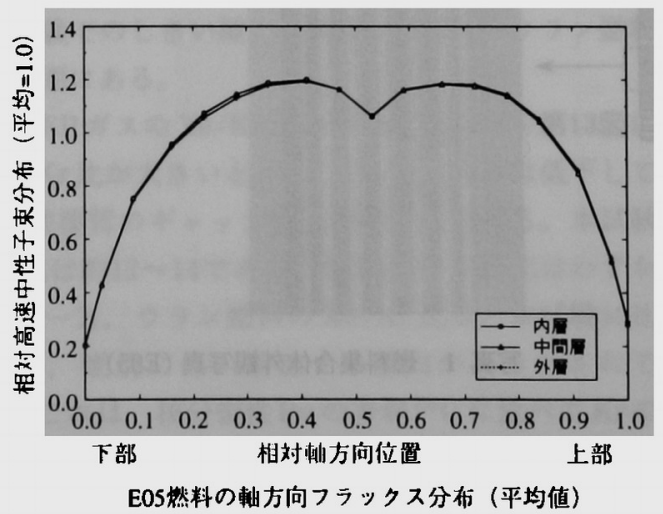

第 6 図 軸方向高速中性子束分布 (E04,E05：寿命平均) 


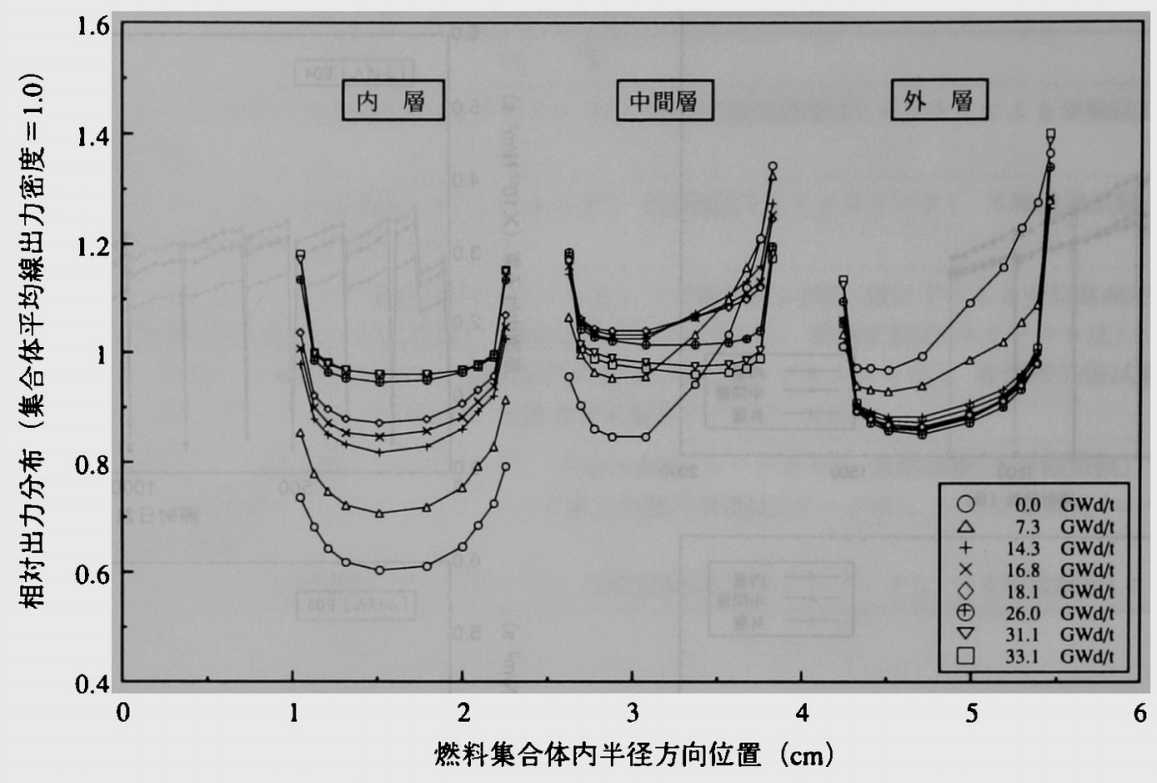

第 7 図 㜣料ペレット内半径方向出力分布 (E04, E05)

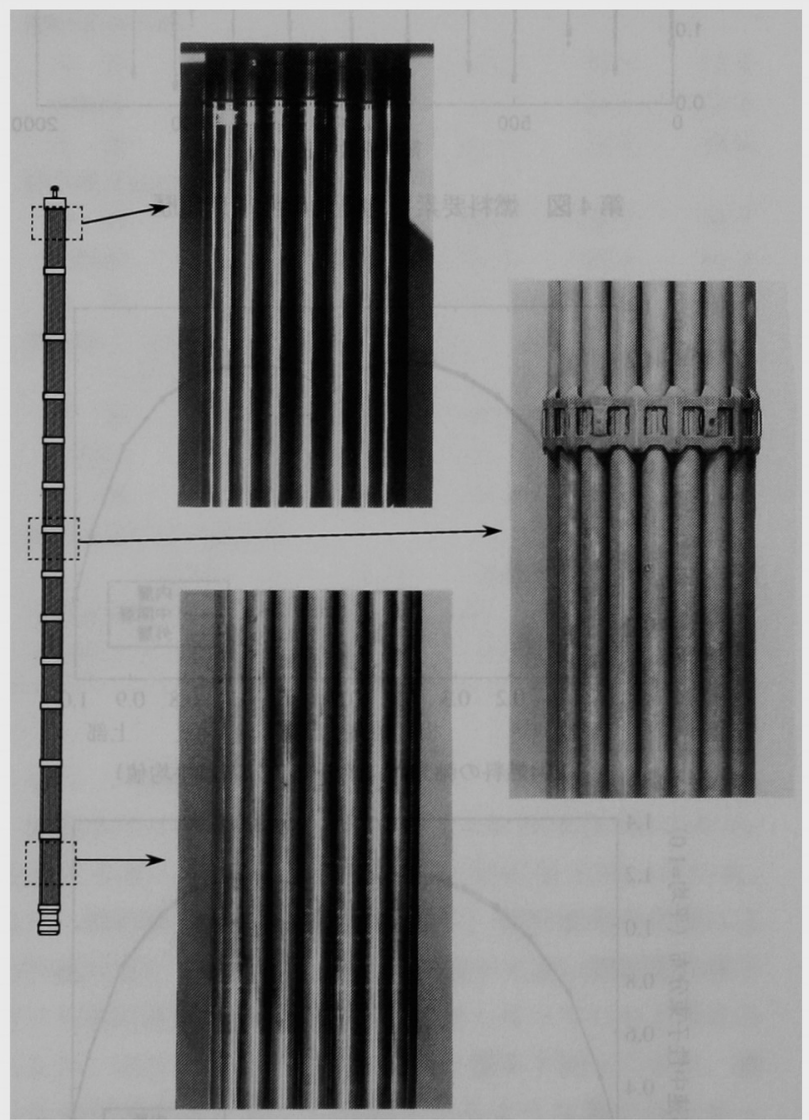

写真 1 燃料集合体外観写真 (E05)

第 9 図に燃料要素平均外径の燃焼度依存性を示す。燃料 要素外径は製造時よりも減少しているが，その減少は飽和 の傾向にある。これは，外圧によるクリープダウンによる 被覆管の外径減少がペレットとの接触により収束するため

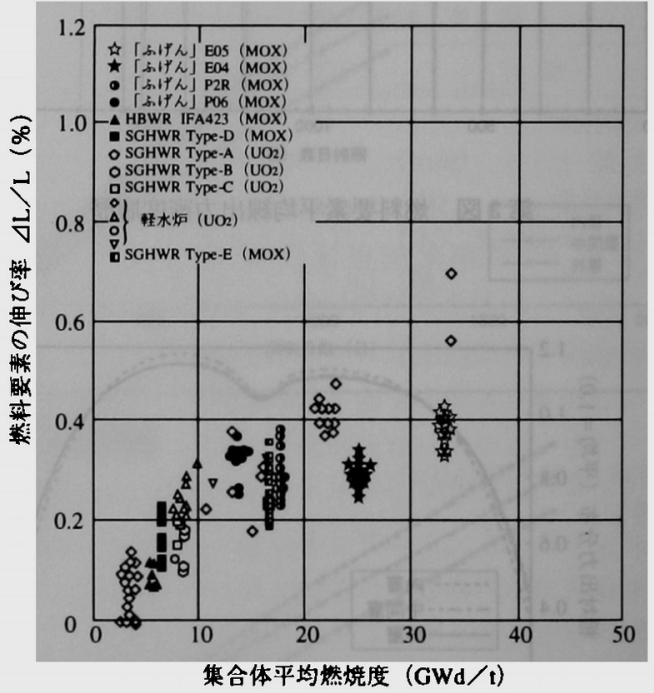

第 8 図 燃料要素伸び率の燃焼度依存性

と考えられる。また, 内首燃料要素の外径減少が比較的大 きいが，これはFPガス放出量が少ないため，外圧による クリープ量が大きいこと, 高速中性子照射量が多いこと等 によるものと考えられる。また, 燃料要素の楕円度につい ても増加していたが, 外径变化と同様, その増加は飽和す る傾向にあった。

\section{（3）燃焼度}

第10図に示すように，イオンマイクロアナライザー (IMA)による ${ }^{145} \mathrm{Nd}$ 分析で求めた燃料ペレット径方向の然 焼度分布の湘定值と計算值(WIMS-E コードによる)はよ く一致していた。また, ${ }^{148} \mathrm{Nd}$ の同位体希釈質量分析で求 めたペレットの燃焼度測定値についても計算值とよく一致 していた。 


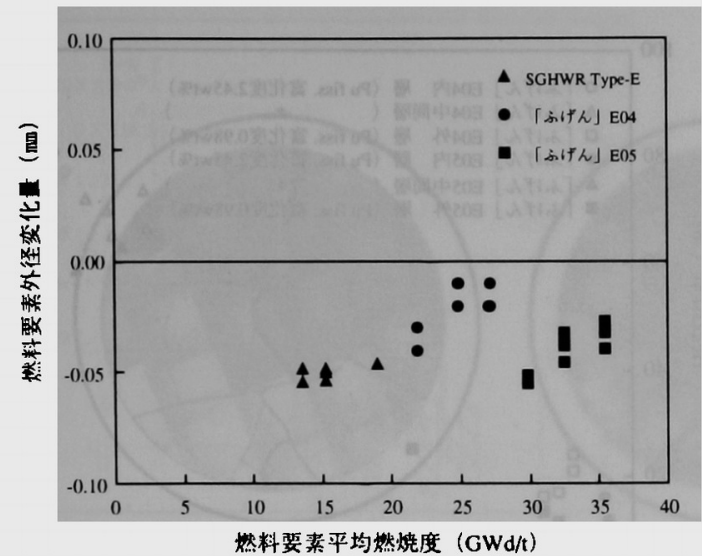

第 9 図燃料要素外径変化の燃焼度依存性

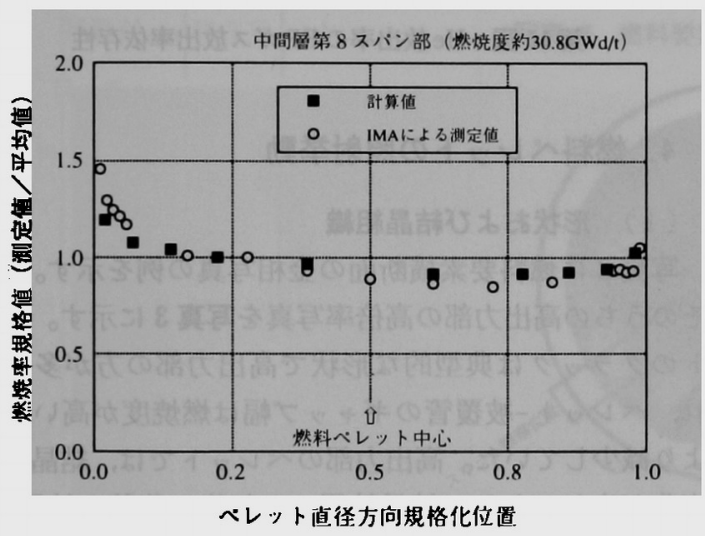

第 10 図燃料ペレット直径方向㒄焼度分布 (E04)

\section{3. 燃料要素内の FP 等の举動}

\section{（1）FPガスの放出挙動}

第11図に FPガス $(\mathrm{Xe}+\mathrm{Kr})$ 放出率の燃烧度依存性を他 の照射データ ${ }^{(1)(2)(4)}$ と併せて示す。本試験での FPガス放 出率は，燃焼度が大きくなると急增するとともにバラッキ る大きくなっており，他の照射データの傾向と一致してい る。BWRゃATR の酸化物燃料では，高温状態での搪散 が主な FPガスの放出機構である。生成した FPガス原子 は，高温では拡散して結晶粒界または粒内において気泡を 形成し，燃焼が進み高温状態が続く之，燃料マトリックス 内でのガス気泡の移動, 結晶粒成長, 結晶粒界での気泡の成 長, 気泡の連結の過程を経て開気孔へ連結するトンネルを 形成し，ペレット外へ放出されるとされている(5)。Vitanza ら ${ }^{(6)}$ は,このようなFPガス放出機構に係るしきい 温度と燃燒度の関係について評価し，FPガス放出率が増 加するしきい温度は，照射初期加ら燃焼度約 $10 \mathrm{GWd} / \mathrm{t}$ に 加けて約 $2,000^{\circ} \mathrm{C}$ 加ら約 $1,300^{\circ} \mathrm{C}$ 一急速に低下するが，以降 の低下は小さいとしている。第12図に $10 \mathrm{GWd} / \mathrm{t}$ 以上の燃 娧度において経験した最大線出力密度と, FP ガス放出率 の関係を他の照射データ (1)(2)(4) と併せて示す。これより， 線出力密度が $25 \sim 30 \mathrm{~kW} / \mathrm{m}$ の範囲を超えると FPガス放出

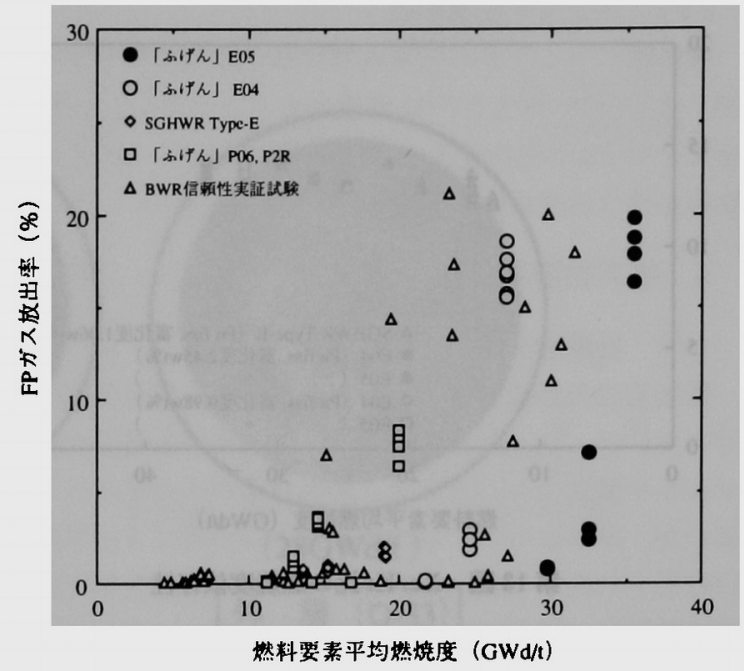

第 11 図 FPガス放出率の然焼度依存性

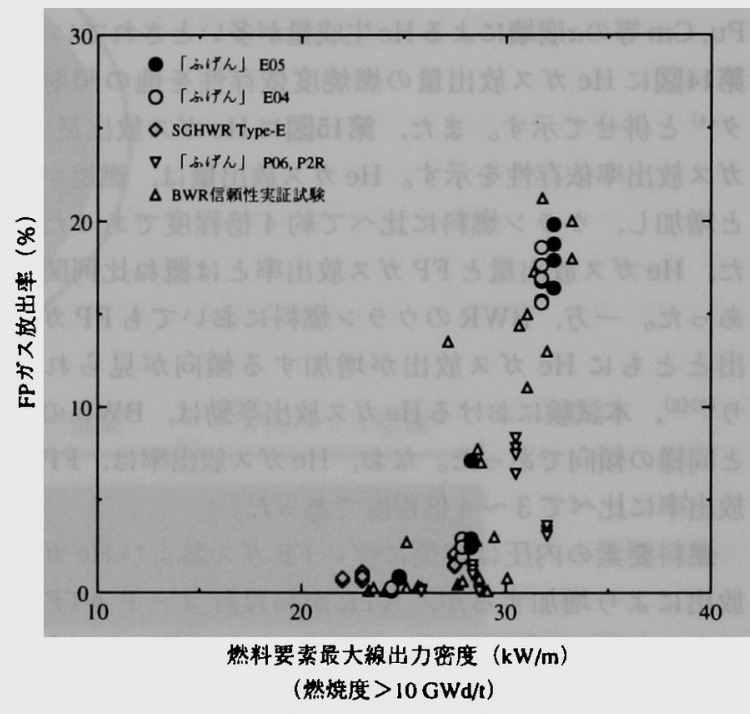

第 12 図 FPガス放出率の線出力密度依存性

率が急増する傾向がみられる。前述のFP ガス放出率が急 增するしきい線出力密度はこのしきい温度に対応してお り、本試験でのしきい線出力密度はBWRのウラン㜣料と 同様の範囲にある。

次に, FPガスの Xe/ $\mathrm{Kr}$ 比の燃焼度依存性を第13图に示 す。Xe/Kr 比が大きいと FPガスの熱伝導度は低下してぺ レットー被覆管のギャップ熱伝達率が低下する。本試験の $\mathrm{Xe} / \mathrm{Kr}$ 比は約 $12 \sim 14$ であり，燃焼に伴う変化はわずかで あった。一方, ウラン燃料の $\mathrm{Xe} / \mathrm{Kr}$ 比は, 本試験に比べ て小さく，然焼に伴い増加する傾向があるとされてい $ろ^{(7)(8)}$ 。これは，核分裂性 $\mathrm{Pu}$ の方が ${ }^{235} \mathrm{U}$ に比べて $\mathrm{Kr}$ の核 分裂収率が小さく，また，Puの核分裂寄与割合はウラン 燃料では燃焼に伴い增加するが，MOX燃料ではあまり変 わらないためであると考えられる。 


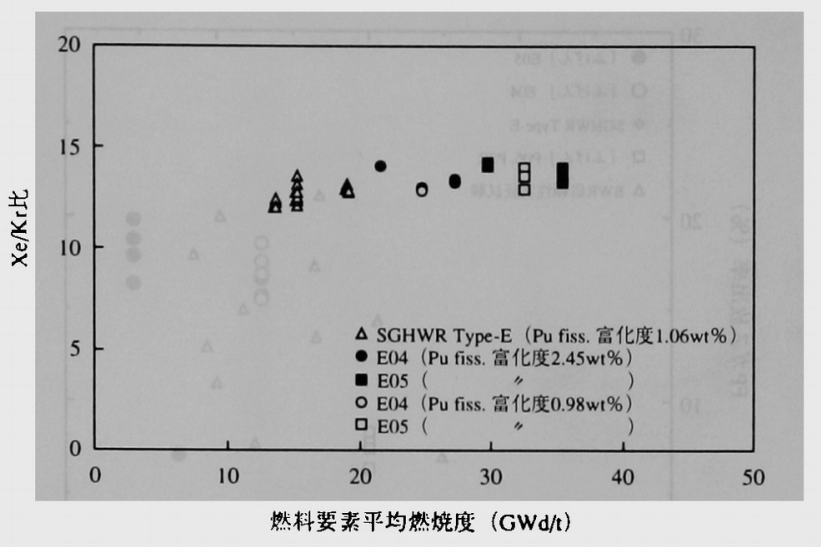

第 13 図 $\mathrm{Xe} / \mathrm{Kr}$ 比の燃烧度依存性

\section{（2） He ガスの放出挙動}

$\mathrm{He}$ が生成される過程には， $\alpha$ 崩壊， $(n, \alpha)$ 反応，三重核 分裂の 3 つがあるが, MOX燃料は, ウラン燃料に比べて $\mathrm{Pu}, \mathrm{Cm}$ 等の $\alpha$ 崩壊による $\mathrm{He}$ 生成量が多いとされている ${ }^{(5)}$ 。 第14図にHe ガス放出量の燃焼度依存性を他の照射デー 夕 $^{(4)}$ 之併せて示す。また, 第15図に $\mathrm{He}$ ガス放出量の FP ガス放出率依存性を示す。He ガス放出量は，燃焼が進む と增加し, ウラン燃料に比べて約 4 倍程度であった。ま た, He ガス放出量と FPガス放出率とは概ね比例関係に あった。一方，BWRのウラン然料においてもFPガス放 出とともに He ガス放出が増加する傾向が見られてお $り^{(4)(5)}$, 本試験における $\mathrm{He}$ ガス放出挙動は，BWRのそれ と同様の傾向であった。なお, He ガス放出率は, FPガス 放出率に比べて 3〜 4 倍程度であった。

燃料要素の内圧は燃焼に伴いFPガスおよび Heガスの 放出により增加するが，ATR 燃料設計コードATFUEL による内圧の予測計算値は実測值に対して約 $11 \%$ 以上大 く評価しており, 設計コードとしての保守性を確認した。

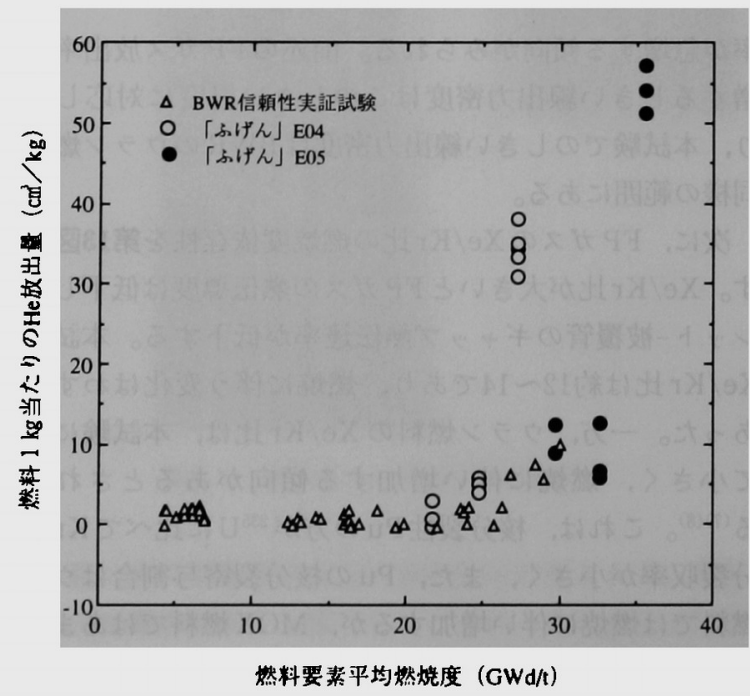

第 14 図 Heガス放出量の燃佬度依存性

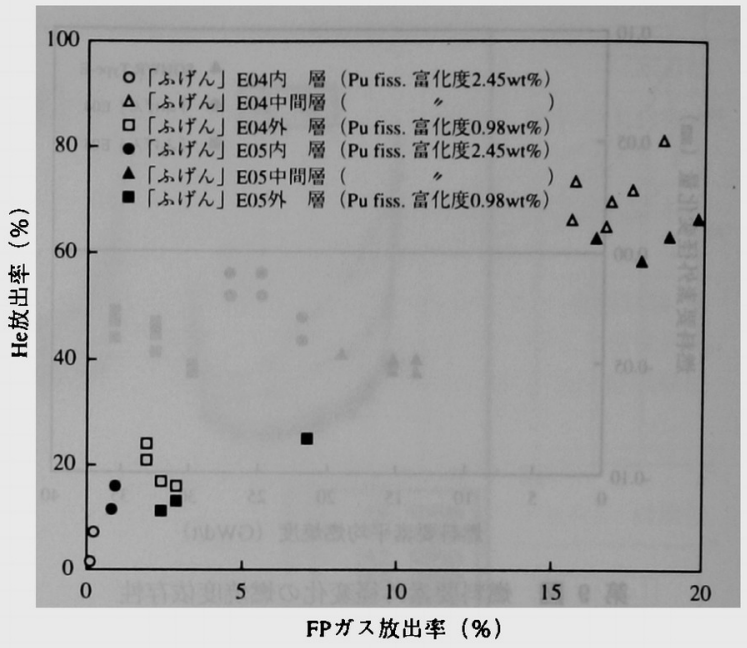

第 15 図 He放出率のFPガス放出率依存性

\section{4. 燃料ペレットの照射挙動}

\section{（1）形状およひ結晶組榓}

写真 2 に燃料要素横断面の金相写真の例を示す。また, そのうちの高出力部の高倍率写真を写真 3 に示す。ペレッ トのクラックは典型的な形状で高出力部の方が多く見ら れ、ペレットー被覆管のギャップ幅は燃焼度が高いものが より減少していた。高出力部のペレットでは, 結晶組織の 变化が生じており, 結晶粒界での気泡の集積や結晶粒(等 軸晶)成長がみられたが，燃料溶融を示すような形跡は認 められなかった。結晶組織变化がみられたぺレットの中心 部の平均結晶粒径は $12 \mu \mathrm{m}$ 程度であり, ペレット周辺部や 低出力部のペレットの結晶粒径は $6 \mu \mathrm{m}$ 程度と製造時とほ とんど変化していない。ペレットの結晶組織变化は，製造 条件，照射条件等に依存する。燃料温度との関係には不確 定性が大きいが，ペレット中心温度が約 $1,500^{\circ} \mathrm{C}$ 以上で等 軸晶成長が顕著となり, 約 $1,700^{\circ} \mathrm{C}$ 以上では柱状晶が形成 される(5)。したがって，ペレット中心に等軸晶成長が見ら れた中間層燃料要素のペレットは約 $1,500 \sim 1,700^{\circ} \mathrm{C}$ 範囲 にあり，等軸晶成長が見られなかった外層然料要素のぺ レットは約 $1,500^{\circ} \mathrm{C}$ 以下であったと推定される。さらに, 結晶組織変化が見られなかった内首燃料要素はFPガス放 出率が $1 \%$ 未満であり，この燃焼度におけるVitanzaによ るFPガス放出率のしきい温度から，その然料中心温度は 約 $1,200^{\circ} \mathrm{C}$ 以下であったと推定される。

ペレット内の Pu分布は外周部が若干高いものの比較的 一様であったが、ところどころにPu濃度が高い多孔質組 織が見られた。この部分は，Puスポットと考えられそ の Pu 濃度は約 $14 \%$ 以下，大きさは $50 \mu \mathrm{m}$ 以下であり， EPMAによる Nd 测定結果から算定した局所燃焼度は, $100 \mathrm{GWd} / \mathrm{t}$ を越える程度であった。また，ペレット外周 の一部に, 約 $50 \mu \mathrm{m}$ の幅の Xe 濃度が低下した多孔質組槽 が観察されたものがあり，EPMAによる Nd 湘定結果か 


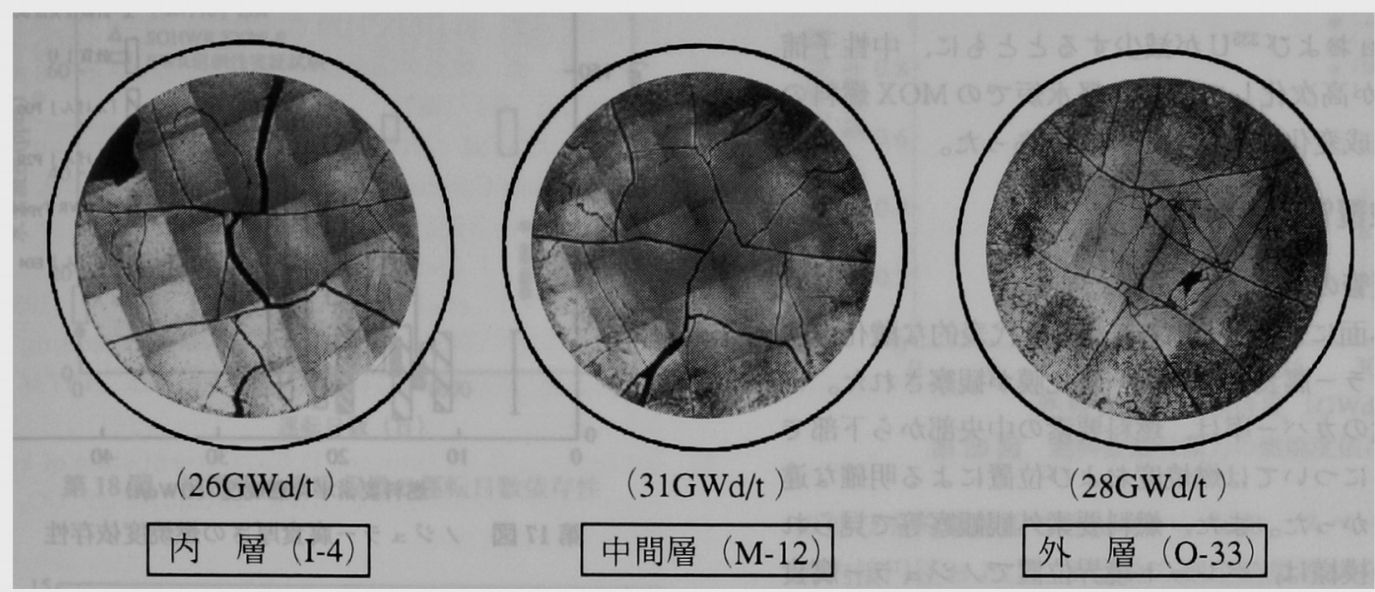

写真 2 燃料要素横断面金相写真 (E04)

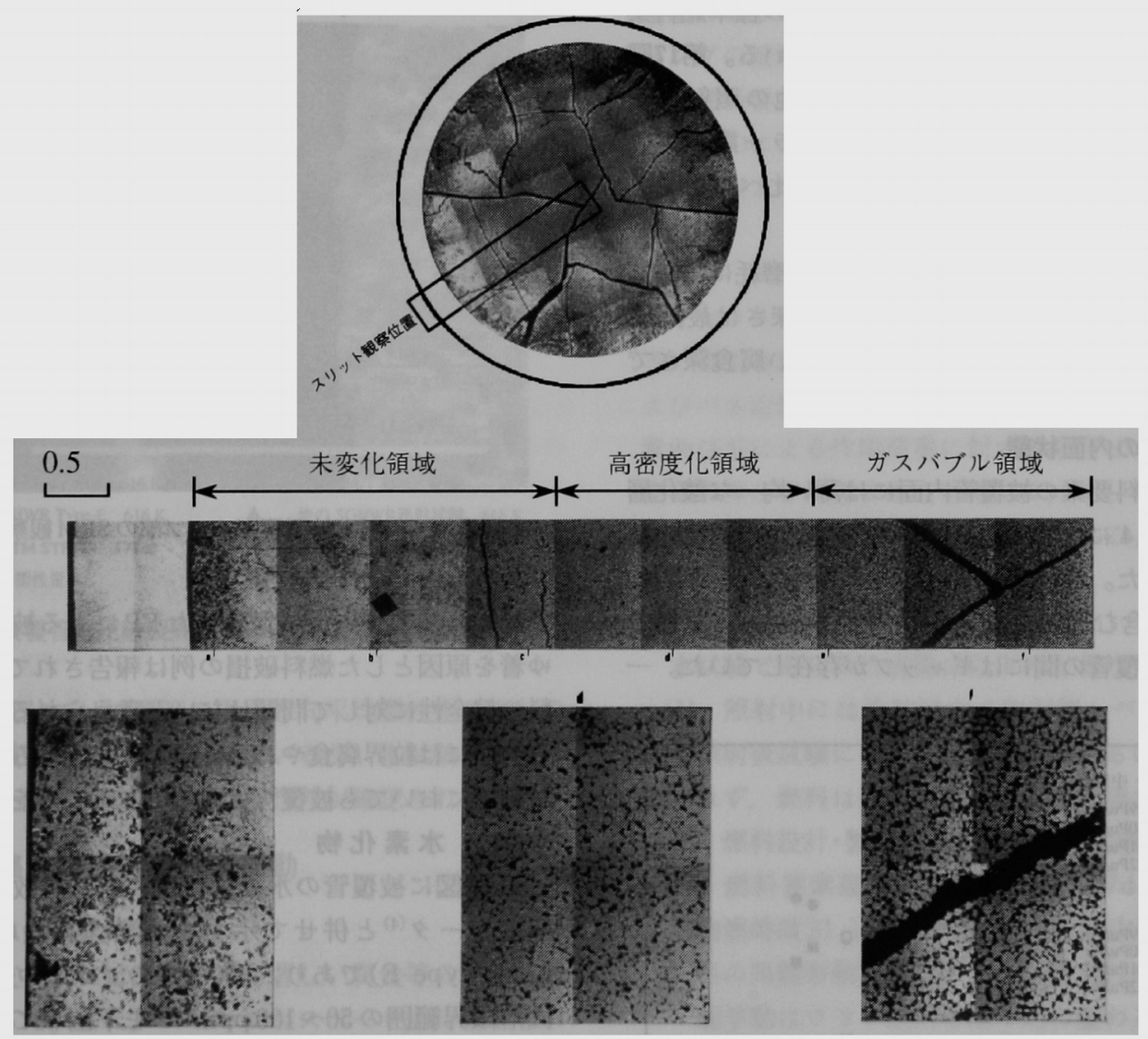

写真 3 燃料ペレット横断面金相写真 (E04) (中間層 M-12 スリット観察位㯰)

ら，その局所燃焼度は $60 \mathrm{GWd} / \mathrm{t}$ 程度であると推定され る。これらの多孔質組織は，高燃焼度のウラン燃料でみら れるリム組織と類似の特徴を有しているが，いずれも局所 的なものであることから，FPガス放出率等に与える影響 はわずかであり，燃料要素全体としてはほとんど無視し得 るあのであると考えられる。

（2）焼きしまりおよびスエリング

ペレット密度は，燃焼初期に焼きしまりによって增加す
るが，燃焼が進むとスエリングにより減少する傾向がみら れた。ペレット密度変化から求めたスエリング率は，約 $0.2 \sim 0.3 \%(\Delta V / V) /\left(10^{20}\right.$ fissions $\left./ \mathrm{cm}^{3}\right)$ であり, BWRの ウラン燃料のデータ(4) とほぼ一致しており，設計で用いて いるスエリング率の妥当性が確認された。またた, 燃料ス タック長は, 焼きしまりにより減少していたが，然料ぺ レットのスエリングにより回復する傾向がみられた。 
（3）ペレット核種組成

第16図にペレットの核種組成の燃焼度依存性を示す。燃 焼に伴い ${ }^{239} \mathrm{Pu}$ および ${ }^{235} \mathrm{U}$ が減少するととすに, 中性子捕 獲によりPuが高次化しておう，軽水炬での MOX 燃料の 燃焼に伴う組成变化の傾向 ${ }^{(5)}$ 之同様であった。

\section{5. 燃料被覆管の照射挙動}

\section{（1）被覆管の外面状態}

被覆管の外面には, BWR でみられる代表的な酸化形態 であるノジュラー腐食と薄い均一酸化膜が観察された。， ジュラー腐食のカバー率は, 燃料要素の中央部から下部で 高いが，厚さについては燃焼度および位置による明確な違 いは見られなかった。また，燃料要素外観観察等で見られ た白色線状の模様は，ペレット境界位置でノジュラ一腐食 が集積(カバー率が高い)している箇所であることがわかっ た。このような白色線状の模様は，「ふげん」の標準燃料集 合体やBWRのウラン燃料 ${ }^{(9)}$ で屯観察されている。第17図 にノジュラー腐食厚さの燃焼度依存性を他の照射デー タ $^{(2)(4)(8)}$ と併せて示す。本試験でのノジュラ一腐食厚さ は, 酸化膜厚さの設計モデル $(16 \mu \mathrm{m} /$ 年 $)$ に比べて十分下 回る值であることが確認された。

スペーサのバネ接触部でのフレッティング磨耗について は，一部のスペーサ部で見られたが，その深さは最大 27 $\mu \mathrm{m}(\mathrm{E} 04)$ であり被覆管の健全性上問題のない腐食深さで あった。

\section{（2）被徨管の内面状態}

高出力部の㜣料要素の被覆管内面には薄い均一な酸化層 のほかに，写真 4 に示すように，局所的な $15 \mu \mathrm{m}$ 程度の反 応層が観察された。この反店層は $\mathrm{Zr}$ とOを含む層と $\mathrm{U}, \mathrm{O}$, TeおよびCsを含む層の 2 層からなうていたが，本試料で はペレットと被覆管の間にはギャップが存在していた。一

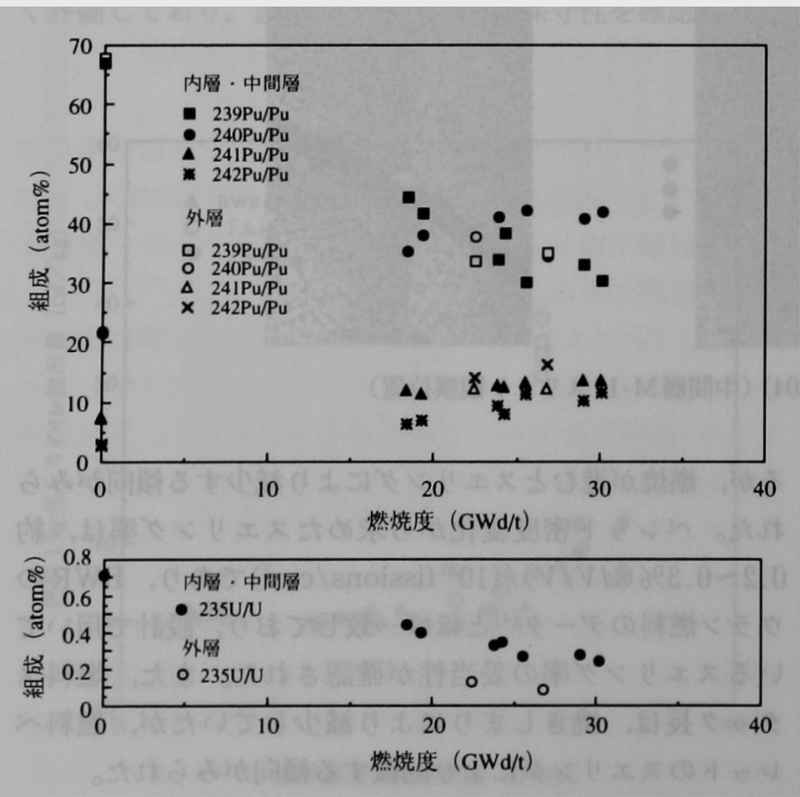

第 16 図 然焼に伴う核種組成の変化 (E04)

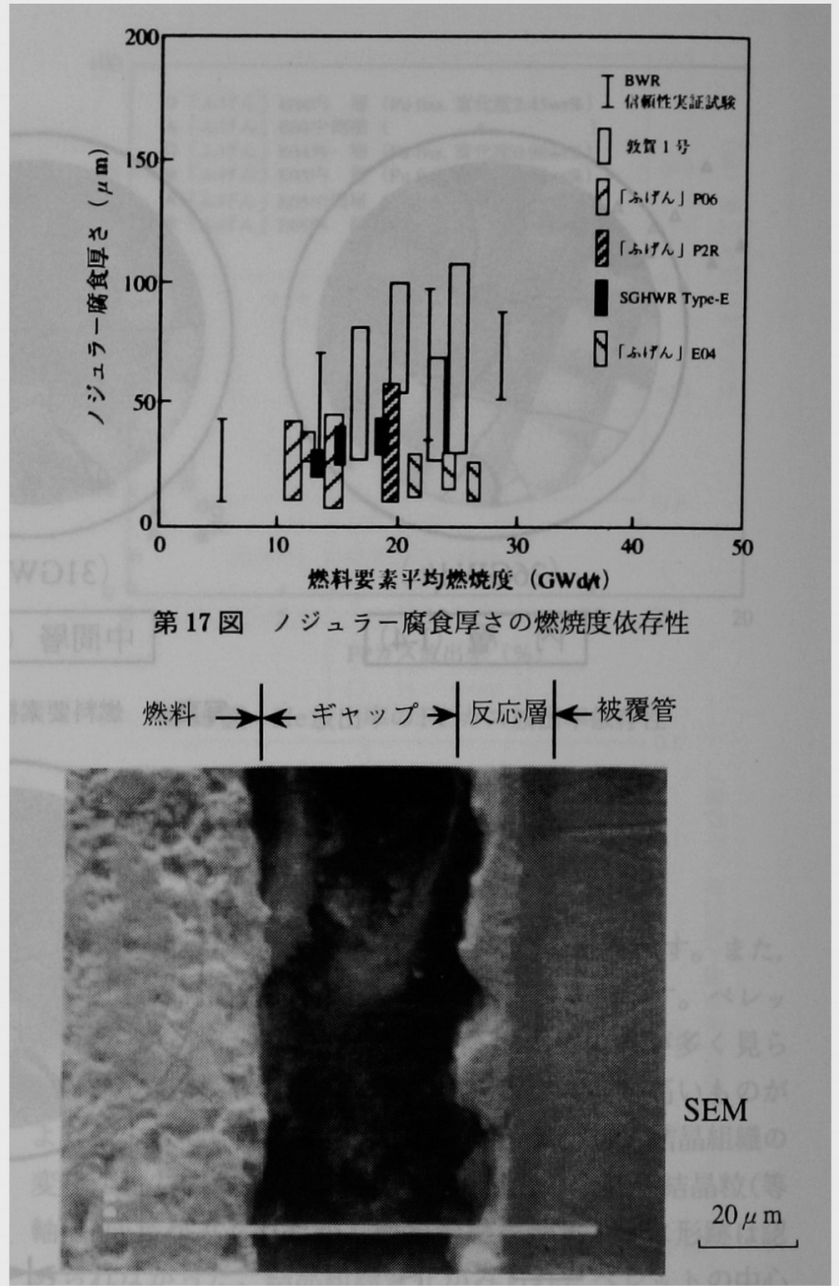

写真 4 矩料と被覆管ギャップ部のSEM観察結果（E04）

般的に, 被覆管内面に付着したFPによる被覆管の脆化や ゆ着を原因とした燃料破損の例は報告されておらず(5)，燃 料の健全性に対して問題はないと考えられる。また，被覆 管内面には粒界腐食やPCMIによる傷等はみられず，金相 試験等においても被覆管は健全であることを確認した。

（3）水素化物

第 18 図に被覆管の水素含有量の運転日数依存性を他の 照射デー夕(4) と併せて示す。水素含有量の最大値は 33

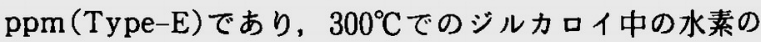
固溶限界範囲の 50〜 $100 \mathrm{ppm}^{(10)}$ を下回っており，運転時 における被覆管の脆化の問題はない。また，水素化物方向 係数 $F_{n}$ は，製造時 $(0.00)$ よりも増加しており，0.08〜 0.14 (E04)であった。Marshall ${ }^{(11)}$ は, $F_{n}$ が0.35以下では 水素化物による影響を受けにくいとしていることから，水 素化物として析出している室温条件においてす被復管の強 度および延性への影敏は小さいと考えられる。

（4）強度および伸ひ

照射に伴い被目管強度の増加および破断伸びの減少は飽 和する傾向にある。第19図に被顠管内圧破裂試験での周伸 びの高速中性子照射量依存性を他の照射データ(12)(13) と併 


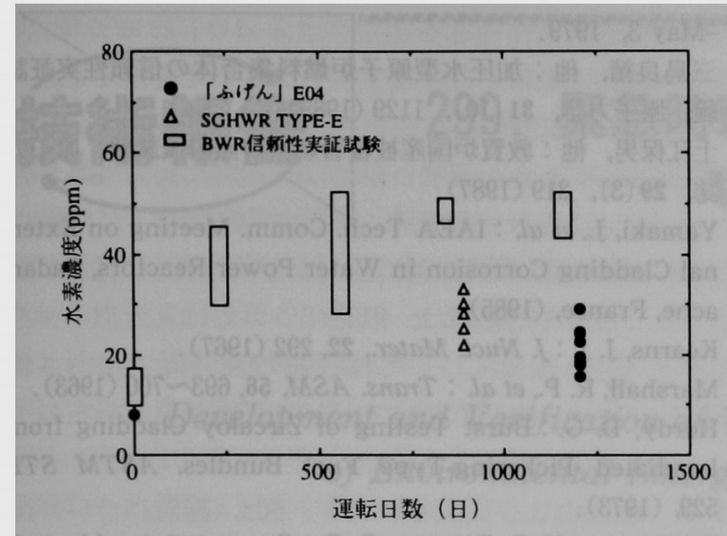

第 18 図 被覆管水素吸収量の運転日数依存性
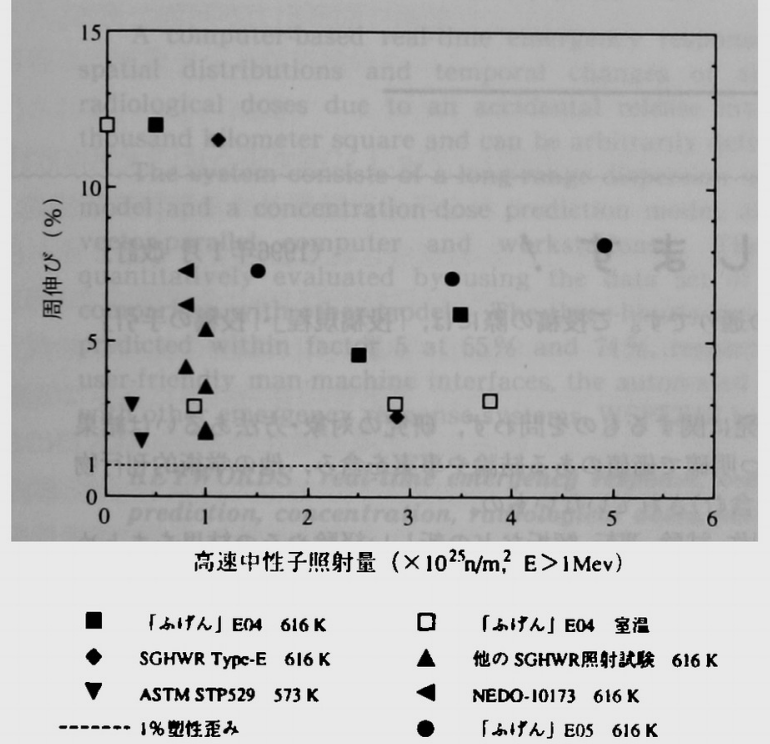

第19図 被覆管内圧破裂周伸びの高速中性子照射量依存性

せて示す。設計では被覆管の円周方向平均塑性歪み $1 \%$ \%を 被覆管の機械的な破損基準としているが，本試験での周伸 びは $1 \%$ \%回っており，その妥当性が確認された。

\section{6. 燃料集合体部材の照射挙動}

\section{（1）スペーサ支持管}

スペーサ支持管には, 变形, 傷, 著しい腐食等の異常は認 められなかった。また，スペーサがスペーサ支持管かしめ 部加逸脱した形跡は認められず，スペーサ支持管のス ペーサ保持機能は健全であったと考えられる。

(2) スペーサ

スペーサには, 変形, 損傷, 腐食等の異常は認められず, 照射後も十分な強度を有していた。

然料要素引抜力は，第20図に示すように，製造時に比べ て低下しているが，その低下はすでに飽和しており，フ レッティング磨耗量す小さいことから，スペーサは十分そ の機能を維持していたと考えられる。また, 燃料要素に顕 著な曲がりは生じていないことから，スペーサは燃料要素

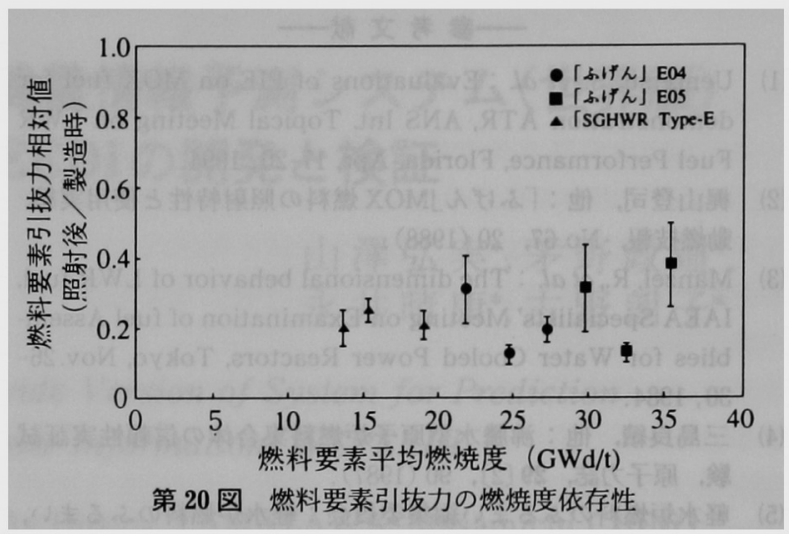

の伸びを拘束することはない。なお，スペーサリング素子 の内接円径およびバネ定数の測定結果等から, 燃料要素引 抜力の低下は, クリープ変形によるリング素子内接円径の 増加および外圧クリープによる被稪管外径減少によるスプ リングの接触荷重の低下に起因していると考えられる。ま た, 燃料要素引抜力が低下し, その後飽和する傾向は, 応 力の緩和によるリング素子スプリングのクリープ変形速度 の低下および被䧗管の外径減少の飽和によるものと考えら れる。

\section{（3）ロッドスプリング}

インコネル製のロッドスプリングには, 変形, 損傷, 腐食 等の異常は認められなかった。また，照射に伴う自由長お よびバネ定数の変化が認められなかったことから, 燃料要 素伸び差による作用荷重に対する余裕は十分にあり，燃料 要素の伸びを拘束することすなく，ロッドスプリングは十 分その機能を維持していたと考えられる。

\section{V. 結 論}

本試験で得られた成果は以下のとおりである。

(1) 照射中には冷却材中の放射能レベルの上昇はなく， 照射後試験において異常な損傷あるいは変形は認めら れず，燃料は健全であることが確認された。

（2）燃料設計·製造の妥当性および信頼性が確認された。

(3) 燃料要素最高燃焼度約 $40.1 \mathrm{GWd} / \mathrm{t}$ (燃料集合体平 均燃焼度 $31.1 \mathrm{GWd} / \mathrm{t}$ )までの, 熱中性子炬用 MOX 燃 料の照射挙動に係るデータが得られた。また，その照 射挙動はウラン燃料之基本的に変わるところはなかっ た。

本試験は, 通商産業省からの委託により, 昭和62年度か ら平成 7 年度にわたり新型転換炉技術確証試験の一環とし て実施したものであり、これにご協力を頂いた多数の関係 者に感謝する。また，これらのデータが，今後の熱中性子 炉用 MOX 然料の利用に関して, その照射挙動の評価, 研 究等の一助となれば幸いである。 


\section{一蒦考文献—}

(1) Uematsu, S., et al. : Evaluations of PIE on MOX fuel for demonstration ATR, ANS Int. Topical Meeting on LWR Fuel Performance, Florida, Apr. 17-20, 1994.

（2）棍山登司，他：「ふげん」MOX 燃料の照射特性と使用実績. 動燃技報，No.67，20（1988）。

(3) Manzel, R., et al. : The dimensional behavior of LWR fuel, IAEA Specialists' Meeting on Examination of fuel Assemblies for Water Cooled Power Reactors, Tokyo, Nov.2630,1984 .

（4）三島良績，他：沸腾水型原子炍燃料集合体の信頼性実証武 験, 原子力誌, 29 [2]，90 (1987).

（5）軽水炉燃料のふるまい編集委員会：軽水炬燃料のふるまい, 原子力安全研究協会, 平成 2 年 7 月.

(6) Vitanza, C., et al. : Fission gas release from $\mathrm{UO}_{2}$ pellet fuel at high burnup, ANS Topical Meeting Portland, Apr. 27
-May 3, 1979

（7）三島良績，他：加圧水型原子吙燃料集合体の信頼性実証試 験，原子力誌，31 (10)，1129 (1989)。

（8）土江保男，他：敦賀炬国産被覆管燃料の照射後試験，原子力 誌, 29 (3), 219 (1987).

(9) Yamaki, J., et al. : IAEA Tech. Comm. Meeting on External Cladding Corrosion in Water Power Reactors, Cadarache, France, (1985).

(10) Kearns, J. J. : J. Nucl. Mater., 22, 292 (1967).

(11) Marshall, R. P., et at. : Trans. ASM, 56, 693 700 (1963).

(12) Hardy, D. G. : Burst Testing of Zircaloy Cladding from Irradiated Pickering-Type Fuel Bundles, ASTM STP 529, (1973).

(13) Williamson, H. E., Ditmore, D. C. : Current state of knowledge high performance $\mathrm{BWR}$ zircaloy-clad $\mathrm{UO}_{2}$ fuel, NEDO-10173, (1970).

\section{投稿を歓迎します！}

(1996年 1 月 改訂)

本会「和文誌」「英文誌」の投稿欄の種別〔(）内は「英文誌」は次の通りです。ご投稿の際には、「投稿規程」「投稿の手引」 に従って執筆願います。(4月号後付に揭載)

(1) 研究論文 (12頁以内)

(2) 技術報告 (12頁以内) (Technical Report)

(3) 疽料(12頁以内) (Technical Data)

(4) 総 説 (12頁以内) (Review)

(5) ショート・ノート (3 頁以内) (Short Note)

(6) 私のメモから ( 2 頁以内) (Technical Memo)

(7) レター( 2 頁以内) (Letter to the Editor)

(8) 談 話 室 ( 2 頁以内)

(9) 国際会議の空 ( 2 頁以内) (Meeting Report) (1ii) 若 風 (1 頁以内)

(11) 会員のこえ(0.5頁程度)

(13) 新刊紹介 $(0.5$ 頁程度)

(14) Research Activity in Japan (Original Paper)

(13) AESJ Information

純学術的なものおよび技術開発に関するものを問わず, 研究の対象·方法あるいは結果 に独創性·創造性があり,功明確で価值のある結論や事実を含み, 他の学術的刊行物 に公表(投稿隼備中のものを含む)されていないもの。

施設·設備·装置などの設計、製作,試験,運転、解析などの新しい経験やその結果をまとめ た実用価値のある内容で，他の学術的刊行物に公表(投稿準備中のものを含む)されて いないあの。必ずしもオリジナリティにとらわれない。

研究・技術に関する参考資料または調查・集計報告などで公表する侮值が認められるも の。

研究分野について，歴史的背景，重要性，進捗状況，今後の発展の方向なよ゙，国内·国外を 問わず幅広く展望したもの。その分野の重要な研究項目がとりあげられ, 要領よく分 類され単なる個別的研究結果の羅列でなく，相互関連が明らかにされているもの。 研究·技術上の独創的かつ重要な発見または結論を含む論文の速報(ミ三論文は不可)。 他優先して掲載する価值があると編集委員会が琶めたもの。後日研究論文として投 稿できる。

研究または技術上の経験,斬新なアイディア，珍しい実験結果など。

揭載論文に対する質疑応答および意見や提案など。（揭載料不要）

トピックスの紹介,随想,時評,紀行文、滞在記など。(同 上) 内外の国際会議·学術的会合の報告·見聞・印象および開催案内。（同上）

テーマは自由：自己紹介や研究分野，本回の運営に対する苦言や提案なよ゙。対象は 30 代 半ばまでの学生を含む若手会員。(同 上)

本会または「本誌」に対する希望・意見などの自由投稿。（誌上医名可，揭載料不要）

会員の役に立ち，興味のあると思われる内外の出版物の書評および紹介。(揭載料不要) 原子力関係内外会議, 外国人受入れプログラムの案内等, 海外向けの情報。(英文誌のみ)

国内の研究機関におけるアクティビティの紹介。（同 上）

巻頭言,特別寄稿,解説, 特集,論説。レビュ一,等は原則として編集委員会で企画して依頼する。

ご投稿の際には，執筆はワープロで，和文はA4 判用紙(26字詰 $\times 24$ 行； 4 枚で刷上り1ページ相当)を，英文はA4判用綪 （ダブルスベース,約10語 $\times 25$ 行； 4 枚で刷上り 1 ベージ相当)を使用し，4月号後付掲載の「投稿票」(付原稿チェックリスト） に所要事項を記入の上, オリジナル 1 部にコピー3 部を添付して事䅂局宛ご送付下さい。 